\title{
РЕАЛІЗАЦІЯ МІЖНАРОДНИХ І НАЦІОНАЛЬНИХ ПРАВОВИХ НОРМ ТА ОРГАНІЗАЦІЙНИХ ЗАХОДІВ ЩОДО ПРОТИДІЇ ПОШИРЕННЮ ІНФЕКЦИЙНИХ ЗАХВОРЮВАНЬ СЕРЕД НАСЕЛЕННЯ
}

\author{
КІКІНЧУК Василь Юрійович - кандидат юридичних наук, доценТ, професор \\ кафедри поліцейської діяльності та публічного адміністрування факультету № 3 \\ Харківського національного університету внутрішніх справ \\ https://orcid.org/0000-0002-1284-2622 \\ УДК: 342.95 (477) \\ DOI:10.32782/NP.2020.2.4
}

Розглядаються методи та способи реалізацї міжнародних та національних правових норм та організаиійних заходів щодо протидіӥ поширенню інфекиійних захворювань серед населення. Зокрема, зазначається, що, враховуючи високий потенційний рівень можливих небезпек, які мають місце при поширенні епідемічних захворювань, представникам державної влади та органів місцевого самоврядування варто якомога швидше розробити та ввести в дію відповідні плани рекомендачій та конкретних дій для профілактики та протидії виникненню $i$ поширенню майбутніх інфекцій. Запропоновані авторсъкі визначення понять «інфекиійне захворювання», "реалізачія правових норм», "реалізачія організачійних заходів» та «протидія поширенню інфекиіӥ».

Актуалізується питання швидкого виникнення та подальшого стрімкого поширення вірусних інбекиій серед населення, а також усунення негативних економічних наслідків, що неодмінно настануть у результаті поширення вищевказаних інфекиій.

Ключові слова: протидія, інфекиійне захворювання, негативні наслідки, короновірус, правові норми, державна політика, економічна стабільність, правова регламентаизія.

Постановка проблеми

Згідно з останніми подіями, що мали місце у більшій частині світу, починаючи 3 кінця 2019 - початку 2020 рр., наразі між країнами поширюється доволі не- безпечна вірусна інфекція, що загрожує іiі носіям можливим летальним результатом (смертю). У загальноприйнятому офіційному мовному обороті ця вірусна інфекція отримала наукову назву COVID-19 (Corona Virus Disease 2019). Як наразі відомо у науковій спільноті, ця інфекція викликається та розповсюджується вірусом SARS-CoV-2, циркуляція якого серед людей була невідомою до грудня 2019 року.

У зв'язку з вищенаведеною небезпекою розповсюдження короновірусу, а також вірогідним поширенням інших інфекційних хвороб у майбутньому, урядам усіх країн світу вкрай необхідно розробити дієві стратегії з протидії подібним загрозам з метою захисту населення.

\section{Стан дослідження}

Стрімка та швидкоплинна тенденція інфекційних захворювань до розповсюдження, а також той факт, що нині існують ще чимало потенційно небезпечних у майбутньому вірусів, проти яких людство все ще не має вакцин, обумовили широкий інтерес наукової спільноти до вивчення проблематики цього питання. 3-поміж інших питань фахівцями у сфері права та публічного адміністрування досліджувалися різноманітні варіації правового регулювання державної протидії вищевказаним небезпекам. Особливу увагу було приділено дослідженню процесу створення та введення в дію якісно прописаних правових норм, які 6 належним чином забезпечували ефектив- 
ну координацію державних органів (служб та відомств) у їх заходах 3 протидії розповсюдженню вірусних захворювань.

Походячи з цього, необхідно констатувати, що науковому дослідженню питань, що так чи інакше є дотичними до основного змісту цієї статті, була приділена значна увага з боку цілої низки авторитетних науковців. А це, у свою чергу, призвело до того, що суспільство наразі має змогу ознайомитись 3 науковими роботами таких учених, як: О. М. Балакірєва, М. В. Буроменський, В. П. Колісник, Г. А. Кохан, І. М. Пінчук, В. М. Стешенко та ін.

Метою цієї статті слід є визначення та класифікація за загальноприйнятими науковими стандартами актуальних організаційних заходів із протидії розповсюдженню інфекційних хвороб з боку державних органів та органів місцевого самоврядування.

\section{Виклад основного матеріалу}

Починаючи із самого початку функціонування перших документально підтверджених державних утворень і закінчуючи сьогоденням, представники політичного керівництва будь-якої держави завжди намагалися (з різним рівнем успіху) протистояти поширенню різноманітних інфекційних хвороб. Здебільшого вони робили це через те, що розглядали масові захворювання як небезпеку своїй владі.

Тобто за умови стрімкого розповсюдження небезпечної інфекційної хвороби настає реальна загроза зменшення популяції осіб, а також припинення активної економічної діяльності в державі, що, у свою чергу, призводить до величезних збитків як людських, так і матеріальних. Саме тому державними діячами залучалися найкращі фахівці у таких сферах, як публічне адміністрування, надання соціальних (у тому числі і медичних) послуг, а також висококваліфіковані правознавці.

Останні були гостро необхідні саме для того, аби, спираючись на норми, що прописані у чинному законодавстві країни, чітко та ефективно розробити дієвий план протидії суспільним небезпекам, одними 3 яких є інфекційні вірусні епідемії. Взагалі варто зазначити, що будь-який напрямок реалізації державної політики аж ніяк не може бути ефективним за відсутності належного правового забезпечення. Це означає насамперед те, що організаційні та інші публічно-адміністративні заходи, що здійснюються установами і відомствами, наділеними державними повноваженнями, мають відбуватися лише на основі чинних праворегулюючих норм законодавства. Тільки дотримання цієї умови дозволить державним органам мати легальне і водночас легітимне підкріплення своєї діяльності, а тому допоможе їм діяти більш впевнено та ефективно [1].

Серед інших позитивних сторін належної правової регламентації процесу реалізації державної політики у вищенаведених ситуаціях можна назвати захист державної системи від зайвої «сумбурності» та шкідливої паніки та страху, які 6 могли значним чином послаблювати і уповільнювати хід практичної реалізації державних заходів. Адже є добре відомим те, що існування у суспільстві так званих «панічних» настроїв завдає величезну шкоду як життю та здоров'ю осіб, так і державному управлінню і економіці країни [2]. Отже, саме стрімка та попередньо продумана, ретельно відпрацьована діяльність державних органів, уповноважених на вирішення подібних проблем, яка базується на чітких та недвозначних правових нормах, і $\varepsilon$ найбільш ефективною формою протидії розповсюдженню епідемій.

Як можна дізнатись 3 аналітичних досліджень діяльності урядів різних держав у періоди минулих пандемій, лише ті держави, служби та відомства яких демонстрували чітку злагодженість своєї роботи та координацію власних дій, змогли досягти найбільш вражаючих результатів у боротьбі 3 масовим розповсюдженням інфекційних захворювань. Іншими словами, прямим результатом їх рішучих дій стала краща, у порівнянні з іншими країнами, статистика захворювань серед населення. Зокрема, до країн 3 найбільш ефективною державною владою, наприклад системою публічного адміністрування, закономірно включають 
Сполучені Штати Америки, Канаду, країни Західної Європи, а також деякі розвинені країни Азії. У цих країнах державна влада демонструє доволі високий рівень ефективності протягом останніх років, що дозволяє висувати впевнені оцінки їх потенційної готовності подолати майбутні ризики.

Варто окремо наголосити на тому, що в контексті активної та безперервної глобалізації, що має місце у XXI сторіччі, все більш значну вагу у подоланні світових криз та конфліктів набирають міжнародні правові норми. До таких перш за все слід включати міжнародно-правові договори, укладені між двома та більше країнами, нормативно-правові акти і декларації організацій об'єднань держав (таких як ООН, EC, НАТО), деякі інші міжнародні документи. Окремо від інших суб’єктів, що здійснюють правове регулювання у міжнародному праві, потрібно виділити міжнародні судові інстанції та арбітражі, що уповноважені вирішувати певний обсяг міжнародних спорів, ускладнених іноземним елементом [3].

Проте, саме у контексті вирішення проблем розповсюдження масових інфекційних захворювань найважливіша роль належить урядам держав, політико-економічним альянсам країн і неприбутковим всесвітнім організаціям, спільна діяльність яких зможе призвести до ефективної протидії небезпекам. Тобто головний обсяг боротьби із подібними кризами покладається саме на «плечі» виконавчої гілки влади. Прикладом цього може слугувати спільна діяльність країн-членів $6 \mathrm{C}$ при подоланні криз.

Питання міжнародної «благодійності» у вирішенні кризових ситуацій також має значущий вплив у функціонуванні міжнародних відносин. Воно полягає у наданні політично та економічно розвиненими країнами фінансової та будь-якої іншої допомоги державам із слабкою економікою і нестабільним політичним режимом. Політичне керівництво розвинених країн йде на такі кроки здебільшого не через «почуття єдності» чи «співчуття», а через абсолютно раціональну і прагматичну послідовну політику, яка здійснюється на основі чітких аналізів та розрахунків.
Мова йде про те, що, враховуючи актуально високий стан згаданого вище процесу світової глобалізації, лідери цілої низки відносно благополучних держав добре розуміють те, що такі небезпеки, як вірусні захворювання, мають ризик до швидкого розповсюдження по території одночасно багатьох країн у різних частинах світу за відносно короткий період часу. Походячи саме зі свого бажання зупинити (або хоча 6 суттєво уповільнити) поширення шкідливих інфекцій у власній країні та у світі загалом, керівники таких держав воліють, не обмежуючись у фінансових витратах, допомогти менш розвиненим країнам у подоланні масових захворювань. Так як більшість країн у світі є просто неспроможною самостійно зупинити поширення різного роду небезпечних інфекцій, їм надається допомога (часом дуже величезна) 3 боку так званих «наддержав» та інших розвинених і благополучних представників світової спільноти.

Задля того, аби національні інтереси держав не заважали їм якісно взаємодіяти одна з одною під час настання пандемічних криз, було наголошено, аби їх діяльність, зокрема і у сфері надання матеріальної допомоги іншим країнам, чітко регламентувалась їх національним законодавством, жодним чином не порушувала зміст їх міжнародних зобов' язань та договорів, тому мала беззаперечну правову позицію. 3 метою вирішення цього завдання уряди країн повинні були тісно співпрацювати 3 найавторитетнішими представниками національної та міжнародної правової галузі. Це робилося з метою недопущення матеріальних та репутаційних втрат держави.

Необхідно констатувати, що при вирішенні таких серйозних проблем суспільства, як інфекційні епідемії всі можливості, які 6 змогли надати корисну допомогу, повинні бути залучені, використані та консолідовані. А для їх належної та ефективної консолідації законодавцям потрібно провести якісну правничу роботу у сфері нормотворчості та правозастосування. Окремим пунктом у подібних законодавчих актах повинна бути прописана та регламентована діяльність різного роду благодійних 
урядових i неурядових неприбуткових організацій, що здійснюють роботу 3 населенням, забезпечуючи нужденних усіма життєво необхідними речами (водою, їжею, медичними препаратами).

Зокрема, серед яскравих прикладів подібних організацій можна виділити ЮНІСЕФ, «Лікарі без кордонів», «Червоний Хрест» та інші об'єднання. Загалом варто зазначити, що, беручи до уваги доволі високий рівень ефективності цих організацій, а також їх неприбутковий характер діяльності, їх робота вже є відносно врегульованою нормативно-правовими актами цілої низки розвинених країн, а також країнжертв певних гуманітарних криз (Сирія, Судан та інші).

Проте, все ще існує чимала кількість держав, законодавство яких є досить далеким від ефективного у наведеній сфері, а тому значною мірою заважає роботі вищезгаданих неприбуткових організацій, перешкоджаючи таким чином дієвій роботі по рятуванню людських життів. На основі цих даних зазначається, що належним чином проведена правотворча робота у сфері протидії інфекційним захворюванням, у якій, 3-поміж іншого, будуть чітко та недвозначно прописані механізми координації та взаємодії між суб'єктами протидії епідеміям, зможе покращити загальну ситуацію із охороною здоров'я у цілому ряді держав, зокрема і в Україні. Деякими науковцями у їх дослідженнях зазначається, що можливість створення дієвої взаємодії між державними установами у їх спільній боротьбі з розповсюдженням інфекційних захворювань, поєднана із координацією зусиль із волонтерськими організаціями, принесе значний успіх [4].

Вітчизняними та зарубіжними спостерігачами слушно зазначається, що актуальні світові тенденції розвитку суспільних відносин стануть вирішальними у формуванні характеру протидії масовому розповсюдженню інфекцій. На практиці це означатиме, що для боротьби з епідеміями, а також для підтримання належного рівня життєдіяльності суспільства під час поширення масових захворювань, урядами держав та іншими суб'єктами будуть активно використовуватись різноманітні високотехнологічні прилади й додатки. Практичними прикладами подібної нової реальності суспільного функціонування стануть можливості дистанційного (через мережу Інтернет) навчання для молоді, а також переведення на дистанційну роботу більшості активно працюючих осіб. Окрім цього, стрімкий розвиток високих технологій у поєднанні із гнучким та динамічним публічним адмініструванням з боку держави створять усі необхідні умови для дистанційної та безконтактної реалізації більшості функцій суспільної життедіяльності. Мова йде про доставку їжі, пошти, медикаментів та іншого набору послуг для широких мас населення.

У свою чергу, роль правової регламентації цих, безумовно, корисних процесів 3 боку законодавчого органу влади має полягати у тому, аби створити максимально широкі та доступні умови для всіх суб'єктів суспільних відносин у їх діяльності. І задля цього нормативно-правові акти, що приймаються законодавчою владою, не повинні створювати зайвих обмежень та перешкод у повсякденному функціонуванні державних органів, під час боротьби останніх 3 інфекційними захворюваннями. Навпаки, прямим призначенням законодавчих актів має бути сприяння повному розкриттю та використанню потенціалу державної влади у іiі діяльності, зокрема і у сфері антиепідемічної боротьби [5].

\section{Висновки}

Отже, підсумовуючи, варто зазначити, що успішне вирішення таких серйозних проблем, як протидія масовим інфекційним захворюванням, потребує одночасної консолідації як міжнародного, так і національного правового компоненту.

\section{入ітература}

1. Про захист населення від інфекційних хвороб: Закон України від 06.04.2000 № 1645-III. Відомості Верховної Ради. 2000. № 29. Ст. 228.

2. Конституція України: від 28.06.1996 р., № 254к/96-ВР. Відомості Верховной Ради Украйни. 1996. № 30. Ст. 141. 
3. Про затвердження Правил санітарної охорони території України: Постанова Кабінету Міністрів України від 22.08.2011 № 893: Офіційний вісник України. 2011.№ 65. Ст. 2538.

4. Про забезпечення санітарного та епідемічного благополуччя населення: Закон України від 24.02.1994 № 4004-XII. Відомості Верховної Ради. 1994. № 27. Ст. 218.

5. Основи законодавства України про охорону здоров'я: Закон України від 19.11.1992 № 2801-XII. Відомості Верховной Ради. 1993. № 4. Ст. 19.

\section{SUMMARY}

Methods and methods of implementation of international and national legal norms and organizational measures to combat the spread of infectious diseases among the population are considered. In particular, it is noted that, given the high potential level of potential hazards arising from the spread of epidemic diseases, representatives of state and local self-government should develop and implement, as soon as possible, appropriate plans of recommendations and specific actions to prevent and prevent the occurrence and spread of property and infection. . The author's definitions of the terms "infectious disease", "implementation of legal norms", "implementation of organizational measures" and "countering the spread of infection" are offered.

The issue of rapid emergence and further rapid spread of viral infections among the population, as well as the elimination of negative economic consequences, which will inevitably result from the spread of the above infections, are actualized.

Keywords: counteraction, infectious disease, negative consequences, coronovirus, legal norms, state policy, economic stability, legal regulation. 